\title{
Vakıf Üniversitelerinin Yatay Geçiş Kampanyaları Kapsamında Yayınladıkları Reklamların Analizi
}

\author{
DOI: $10.26466 /$ opus.732714
}

\author{
* \\ Evin Doğan $^{*}-$ Elif Miral Oktay ${ }^{* *}$ \\ *Dr. Öğr. Üyesi İstanbul Şişli Meslek Yüksekokulu, İstanbul, Türkiye \\ E-Posta: evin.dogan@sisli.edu.tr \\ ORCID: 0000-0003-1441-3968 \\ **Öğr. Gör. İstanbul Şişli Meslek Yüksekokulu, İstanbul, Türkiye \\ E-Posta: elifmiral.oktay@sisli.edu.tr \\ ORCID: 0000-0001-6949-2101
}

\begin{abstract}
Öz
Yatay geçiş, üniversiteler veya yüksekokullarda eğitim/öğretim gören öğrencinin, aym düzeydeki başka bir bölüm veya programda öğrenime devam etmesidir. Kurum içi ve kurum dışı olmak üzere iki şekilde yapılan yatay geçiş kapsamında öğrenciler eğitim-öğretim gördükleri bölümden başka bir bölüme veya başka üniversiteye geçiş hakkına sahip olmaktadır. Yükseköğretim Kurulu (YÖK) tarafindan yapılan düzenlemeler ile birlikte, yatay geçişler vakıf üniversiteleri için giderek daha fazla önem kazanmaya başlamıştır. Vakıf üniversiteleri, öğrenci sayısının artmasını sağlayan yatay geçiş sistemine yönelik, reklam ve tanıtım faaliyetlerine ağırlık vererek, çeşitli kampanyalar yürütmektedir. Bu çalışma, bilgi üretme, yayma ve toplumsal fayda sağlama misyonu ile tanımlanan üniversitelerin, yatay geçiş süreçlerinde yürüttü̈̆̈̈ reklam kampanyalarına odaklanmıştır. Amaç, eğitim ve araştırma odakl, bilimsel bilgi üretme ve topluma sunma, öğretim ve akademik çalışmalar yapma misyonu ile tanımlanan bilim ve eğitim kuruluşu olan üniversitelerin yatay geçiş döneminde yayınladığı reklamları analiz ederek üniversitelerin toplumsal misyonları bağlamında değerlendirmektir. Araştırma kapsamında elde edilen verilere göre, vakıf üniversitelerinin yatay geçiş reklamlarında, misyon ve vizyonda belirtilen temel değerlere yer verilmemekte, indirim/burs olanakları öne çıkartılarak, ticari reklamlarda kullanılan satışa özendirme stratejisi kullanılmaktadır. Üniversitelerin misyon ve vizyon tanımlarında yer verdikleri "toplumsallık", "bilime katkı", "bilgi üretme" gibi evrensel ilkeleri doğrultusunda tanıtım stratejisi izlemesi, üniversitelere yönelik "ticarileşme" algısına etki edebileecek önemli değişim/dönüşümler içerecektir.
\end{abstract}

Anahtar Kelimeler: kampanya, vakıf üniversitesi, yatay geçiş, reklam. 


\title{
Analysis Of Advertisements Campaigns That The Foundation Universities Published Under The Undergraduate Transfer
}

\begin{abstract}
Undergraduate transfer refers to the pursuance of education of a higher education student in another program or department with a similar grade of the former. Applied in two methods, internal or external, students have rights to transfer to another department internally or another university within the context of the undergraduate transfers. Following the latest regulations made by the Council of Higher Education (YÖK), undergraduate transfers gained a gripping attention of private universities. Private universities started major commercial campaigns for the undergraduate transfers which gives a massive boost to the increase of student quantity.

This study is focused on the advertisement campaigns of undergraduate transfer processes of private universities, which are, in contrast, defined with the mission of generating information, disseminating and providing social benefit. The aim is to analyze the advertisements launched by universities during the transfer period, and evaluate them in the context of universities' social missions, which are defined as science and education institutions focused on education and research, producing scientific knowledge and disseminating it for public benefit. Considering the data collected during this research, universities, ignoring the primary functions and values of their vision $\mathcal{E}$ mission definitions, promote discount and scholarship opportunities and stimulate commercial marketing strategies. Universities should pursue marketing strategies with universal values defined in their vision $\mathcal{E}$ mission discourse such as "collectivism", "scientific contribution" and "production of knowledge", which in return might help universities transform/reverse the perception of commercialization.
\end{abstract}

Keywords: Campaign, private university, transfer, ad 


\section{Giriş}

Üniversiteler, bilimsel üretim, eğitim, araştırma ve meslek kazandırma işlevlerinin yanı sıra ekonomik ve sosyal kalkınma, politik bilinç ve demokratikleşmede önemli role sahiptir. Evrensel ilkelerle bilginin üretildiği ve yayıldığı, toplumun hizmetine sunulduğu alanlar olan üniversiteler, toplumun değişim dönüşümünde önemli misyon üstlenmektedir. Toplumsal alandaki gelişmeler ile politik, ekonomik ve kültürel yapı da üniversiteleri etkilemekte ve yeniden biçimlendirmektedir. Üniversiteler, her devletin kendine özgü tarihi gelişimi ve sosyo-kültürel yapısı ile şekillenmekte, belli bir karakteri taşımaktadır (Bingöl, 2012).

Sosyo-ekonomik veya politik sistemlerinden etkilenen üniversiteler, özellikle 1980'li yıllardan itibaren küresel düzeyde yaşanan politik iktisadi gelişmelerle yeniden biçimlenmeye başlamıştır. Toplumsal fayda sağlamak üzere bilgi ve bilimin üretildiği ve yaygınlaşttğı merkezler olarak tanımlanan üniversiteler, ticarileşme/şirketleşme kapsammda, bilimsel faaliyet yürüten kurumlar olmaktan çıkarılmış, işletme gibi verimli çalışması istenen kurumlara dönüştürülmüştür (Baskan, 2001). Küresel kapitalizmin ihtiyaçları doğrultusunda ve neo-liberal politikalarla tıpkı ticari şirketler gibi yeniden yapılandırılmaya başlanan üniversiteler, toplumsal fayda ve kamu yararı ilkesi yerine serbest piyasa ilişkileri kapsamında kar sağlanan bir alan olarak yeniden tanımlanmaya başlamıştır (Karaboğa, 2018). Üniversitelerin ekonomik girdi ile sınayi kalkınmayla ele alınması ise üniversitelerin toplumcu, aydınlamacı, demokrasi ve kültürel gelişime katkısını arka plana itmiştir.

Girişimcilik ve kar güdüsünün akademiye girmesini "akademik kapitalizm" kavramı ile açıklayan Slaughter'e göre, ulusal politikadaki değişiklikler ve devletin destek payındaki düşüşler akademik kapitalizme neden olmaktadır. Üniversiteler, ulusların sahip olduğu en kıt ve değerli insan ve bilgi sermayesinin depolarıdır. Aynı zamanda küresel ekonomide başarılı bir şekilde rekabet edebilmek için yüksek teknoloji ve teknolojinin geliştirilmesi için gereklidir (Slaughter, 1997) Üniversite sanayi işbirlikleri, teknoparklar, araştırma geliştirme laboratuarları, kariyer merkezleri, girişimci üniversite, markalaşma, rekabetçilik ve şirketleşme bu dönemin ön plana çıkan unsurlarıdır. Eğitimin ve bilimin ticarileşmesi, üniversitelerin piyasa ekonomisine dahil edilmesi, üniversiteler açısından köklü dönüşümün te- 
mel göstergeleridir. Dolgun'a göre, üniversitelerin bilimsel araştırmalar için kaynak yetersizliği ve bütçe kısıtları, diğer yandan kapitalist rekabet döneminde işletmelerin araştırma geliştirme faaliyetleri ve teknoloji temelli profesyonel meslek elemanlarının sektöre kazandırılması ihtiyacı neticesinde, üniversitelerin eğitim hedefleri şirket stratejileri ile uyumlaştırılmakta, üniversiteler huzla ticarileşmektedir (Dolgun, 2011). Üniversite sanayi işbirliklerinin gerekçesi olarak, üniversitelere kaynak oluşturma, teknoloji transferine imkan tanıma, bilgi ve teknoloji üretimi ile ekonomik kalkınmaya katkı sunma ve sosyal fayda sağlamak gösterilmektedir. Bu yaklaşıma göre üniversitelerdeki bu dönüşüm süreci;

"Şirketlere yeni iş imkanları yaratmak, girişimciliği desteklemek ve yenilikçi şirketleri olgunlaştırmak, üniversiteler ve şirketler arasındaki sinerjiyi artırmak suretiyle ekonomik kalkınmaya katkı sağlamak ve böylece rekabet gücünün artırılmasına katkıda bulunmaktadır." (Ersun, 2011)

Türkiye'de üniversiteler geçmişten günümüze sosyo-ekonomik ve politik gelişmelere paralel olarak; özellikle 1980 Askeri Darbesi'nin ardından kurulan Yükseköğretim Kurumu (YÖK), idari ve mali özerklik, akademik ve bilimsel üretim, eğitim öğretimin kalitesi gibi pek çok alanda sorun ve çözüm arayışlarıyla gündeme gelmiştir. 2000'li yıllardan itibaren; vakıf üniversitelerinin sayısının huzla artması, her ilde devlet üniversitelerinin kurulması ve "Yeni YÖK" düzenlemelerinden oluşan yükseköğretim politikaları ile üniversitelerde demokratik yönetim ve katılımcılık alanındaki yetersizlikler, bilimsel yayın ve akademik üretim eksikliği, eğitim ve öğretimde kalite düşüklügü̈, teknik ekipman ve donanım yetersizliği, işsizlik ve istihdam sorunları, plansızlık, ticarileşme gibi sorunlar, gerek akademik dünyada gerekse sivil toplum alanında tartışmaların odağında yer almıştır. YÖK tarafından hazırlatılan "Yükseköğretim Stratejisi" başlıklı rapor, TÜSİAD'ın Avrupa Üniversiteler Birliği Kurumsal Değerlendirme Programı kapsamında hazırladığ1 "Türkiye'de Yükseköğretim: Eğilimler, Sorunlar ve Fırsatlar" başlıklı raporu, Dış Ekonomik İlişkiler Kurulu'nun hazırladığı Uluslararası Yüksek Öğretim ve Türkiye'nin Konumu başlıklı raporu, İstanbul Politikalar Merkezi'nin yayınladığı "Neden Yeni bir Yükseköğretim Vizyonu?" başlıklı çalışması, Eğitim Sen'in hazırladığı OHAL Sonrası Türkiye'de Üniversiteler Raporu, Türk Eğitim Sendikası tarafından yürütülen, “Türkiye'de Yükseköğretimin Sorunları, Beklentiler ve Çözüm Arayışları Çalıştayı" ve komisyon raporları, Eğitim Bir Sen tarafından hazırlanan "Yükseköğretime 
Bakış 2019 İzleme ve Değerlendirme Raporu" üniversitelere ilişkin yürütülen tartışmalara yönelik güncel örneklerdir.

Tarihi süreç içerisinde piyasadan çok uzak olmayan modern üniversitelerde ticarileşme bağlamında yaşanan asıl dönüşüm süreci, vakıf üniversitelerinin kurulması ile farklı bir boyut kazanmıştır. Türkiye'de vakıf üniversitelerinin ortaya çıkışı, serbest piyasa ekonomisine geçiş ile devletin ekonomideki gücünün belirli çerçevede daraltılıp, piyasalaşmaya uyumlu politikalara ağırlık verilen döneme denk gelmiştir. Eğitim ve öğretim hizmetleri kapitalist sisteme ayak uydurularak piyasaya açılmış ve bu alanı sermayenin hizmetine sunulmuştur. (Bektaş, Fidan, ve Keçeci, 2011) Ankara'da kurulan Bilkent Üniversitesi Türkiye'de ilk vakıf üniversitesi olmuştur. 1992 yılında çıkarılan 3785 sayılı yasa ile resmi olarak vakıf üniversitesi statüsü kazanan ilk vakıf üniversiteleri; Bilkent Üniversitesi ile Kadir Has Üniversitesi ve Koç Üniversitesidir. 1992 yılının ardından vakıf üniversitelerinin sayısı artmaya başlamıştır. 2020 yılı itibariyle, ülke genelinde toplam 72 vakıf üniversitesi faaliyet yürütmektedir. Ayrıca 5 vakıf meslek yüksekokulu da yüksek eğitim öğretim faaliyetinde bulunmaktadır.

Vakıf Yükseköğretim Kurumları Yönetmeliğine göre, vakıf üniversiteleri ticari bir işletme olarak değil, "kamu tüzel kişiliğine sahip, yüksek düzeyde araştırma, eğitim-öğretim, bilimsel araştırma, yayın ve danışmanlık yapan yükseköğretim kurumudur." (Cumhurbaşkanlı̆̆ Mevzuat Bilgi Sistemi, 2020). Vakıf üniversitelerinin niteliği Anayasa'nın 130. maddesinde ise şöyle tanımlanmıştır: "Kanunda gösterilen usul ve esaslara göre, kazanç amacına yönelik olmamak şartı ile vakıflar tarafından, Devletin gözetim ve denetimine tabi yükseköğretim kurumları kurulabilir." (Cumhurbaşkanlığı Mevzuat Bilgi Sistemi, 2020). Mevzuat dikkate alındığında vakıf üniversitelerinin ticari kazanç amaciyla faaliyet yürüten bir "ticarethane" niteliğinde değerlendirilmemesi beklenmektedir. (Budak, 2010). Kamu kurumu niteliğinde derlendirilen ve kar amacı taşımayan eğitim-öğretim kuruluşları olarak tanımlanan vakıf üniversiteleri, son yıllarda gerek devlet gerekse vakıf üniversitelerinin çoğalması ve artan rekabet ortamı ile birlikte, piyasa mekanizmalarıyla uyumlu hale gelmeye başlamıştır. Vakıf üniversiteleri, serbest piyasa içerisinde yer alan ticari işletmeler gibi çeşitli tanıtım, satı̧ ve pazarlama stratejilerini kullanmaya yönelmiştir. Amaç, aday öğrencilere ulaşarak hedeflenen öğrenci kontenjanını doldurmak ve aynı zamanda kurumsal anlamda pozitif bir imaj oluşturmaktır. Vakıf üniversiteleri, özellikle tercih 
dönemlerinde yayınladıkları tanıtım filmleri, ilanlar ve reklamlar aracılığıyla hedef kitleyle buluşmaya odaklanmakta, hedef kitlenin tercihlerini, yönelimlerini etkilemeye çalışmaktadır.

Bir ürünü tanıtmak, ürünün satışını sağlamak, kurumsal kimlik veya marka bilinirliğini sağlamak üzere hazırlanan reklamlar, bir kişiyi belirli bir ürün veya hizmeti almaya ikna etmek için kullanılan ücretli bir iletişimdir (Einstein, 2017). Reklamlar, tüketicinin tercihlerini belirlemek/etkilemek veya satın alma/tüketme ihtiyacı ortaya çıkarmak üzere hazırlanan, ikna ve yönlendirme amaçlı mesajlar bütünüdür. Satışa sunulan mal ve hizmetlerin değişim değerini güçlendiren reklamlar, daha önce meta olarak kabul edilmeyen mal ve hizmetleri de metaya dönüştürür (Goldman, 1992). Vakıf üniversiteleri, markasını tanıtmak, görünürleştirmek ve popüler hale getirmek için bir eğitim kurumundan ziyade, bir işletme veya şirket gibi davranmaktadır. Dolayısıyla vakıf üniversiteleri, reklam ve tanıtım mekanizmalarını bir girişimci mantığıyla işletmektedir. Reklam ve tanıtım faaliyetleri, "kamusal yarar" adı altında gizlenmekte ve verilen mesajlar belirli sosyal kalıplar içinde yinelenmektedir. (Değirmencioğlu ve İnal, 2015)

Vakıf üniversiteleri tarafından beyan edilen verilere göre, reklam ve tanıtım faaliyetlerine yüksek oranda bütçe ayrılmaktadır. Yükseköğretim Kurumları 2019 raporuna göre; Bahçeşehir Üniversitesi'nin reklam ve tanıtım bütçesi 16.802.469,94 TL, İstanbul Esenyurt Üniversitesi'nin bütçesi 13.874.468,46 TL, İstanbul Aydın Üniversitesi'nin 12.339.687,79 TL, Maltepe Üniversitesi'nin 10.966.688,22 TL, İstanbul Gelişim Üniversitesi'nin ise 10.739.946,75 Türk Lirasıdır. Vakıf üniversitelerinin reklam-tanıtım için ayırdığ toplam bütçe 219 milyon 476 bin 23 TL'ye ulaşmıştır. (Yükseköğretim Kurumu, 2020).

Vakıf üniversitelerinin tanıtım reklam çalışmaları; ekonomik-politik düzlemin yansımalarını içermektedir. Dağtaş ve Ünal'ın çalışmasına göre, son dönemde artan işsizlik ve üniversite mezunlarının iş bulamama sorununa yönelik iş imkânı sağlayan ve sanayi alanıyla işbirliği içerisinde uygulamalı eğitim veren üniversite temaları reklamlarda işlenmekte, gelecekle ilgili umut vaat eden sloganlar kullanılmaktadır. Vakıf üniversiteleri reklamlarda, geleceği pazarlayan ve maddi bir kazanç elde etme amacını saklı tutan bir reklam stratejisi izlemektedir (Dağtaş ve Ünal, 2019). Vakıf üniversitelerinin basın ilanlarının incelendiği bir çalışmada ise, yurt dışı olanakları, kariyer fırsatları, burslar ve nitelikli eğitim vaatlerinin öne çıktı̆̆ tespit edil- 
miştir. İlanlarda çoğunlukla "gelecek", "dünya", "başarı" ve "tercih" kelimelerinin kullanıldığı görülmüş̧ür. (Yıldız, 2014). Basın ilanlarının yanı sıra, daha çok dijital ortamlarda paylaşılan video reklamlarda da aynı mesajların kullanıldığı görülmektedir. Reklamlarda farklı konseptler kullanılsa dahi; özellikle bireysel başarı, mutluluk, kariyer, iş firsatları öne çıkarılmakta; kampüs olanakları, sosyal aktiviteler ve eğlence birer görsel şölen eşliğinde izleyiciye sunulmaktadır.

\section{Araştırmanın Amacı ve Yöntemi}

Vakıf üniversiteleri genel olarak tercih dönemlerinde reklamlara ve tanitım faaliyetlerine ağırlık verse de, yatay geçiş dönemlerinde de reklam kampanyaları yoğunlaşmaktadır. Yatay geçiş, bir yükseköğretim kurumunda kayıtlı olan öğrencinin, aynı düzeydeki diğer diploma programlarında öğrenime devam etme hakkı kazanması olarak tanımlanmaktadır. 21 Ekim 1982 tarihli 17845 sayılı Resmî Gazete'de yayımlanan Yükseköğretim Kurumları Arasında Önlisans ve Lisans Düzeyinde Yatay Geçiş Esaslarına İlişkin Yönetmelik ile yükseköğretim kurumlarında yürütülen yatay geçişlerde, 24 Nisan 2010 tarih ve 27561 sayılı Resmi Gazete'de yayınlanan Yükseköğretim Kurumlarında Önlisans ve Lisans Düzeyindeki Programlar Arasında Geçiş, Çift Anadal, Yan Dal İle Kurumlar Arası Kredi Transferi Yapılması Esaslarına İlişkin Yönetmelik ile ön lisans programları da dahil edilmiş, 2015 yllında da Ek Madde 1 düzenlemesi ile, yatay geçiş işlemleri için başvuruların güz ve bahar dönemi olmak üzere yılda iki kez yapılmasına olanak sağlanmıştır. Yatay geçişin kapsamı ve başvuru olanağının genişlemesi ile birlikte, üniversiteler arasındaki yatay geçiş oranı dikkat çekici boyutlara ulaşmıştır.

Bu çalışma, öğrenci adaylarına web siteleri ve sosyal medya paylaşım ağlarıyla ulaşmaya çalışan vakıf üniversitelerinin, yatay geçiş başvuru dönemlerinde yürüttükleri reklam/tanıtım kampanyalarına odaklanmaktadır. Amaç, kamu yararı doğrultusunda bilimsel bilgi üretme, eğitim, öğretim ve araştırma faaliyetlerinde bulunma misyonu ile tanımlanan üniversitelerin yatay geçiş döneminde yayınladığı reklamları analiz ederek, üniversitelerin toplumsal misyonları bağlamında değerlendirmektir. Çalışma kapsamında aşağıdaki sorulara yanıt aranmıştır: 
1. Vakıf üniversitelerinin yatay geçiş kampanyalarında kullandıkları sloganlar ve öne çıkardıkları temalar nelerdir?

2. Vakıf üniversiteleri, yatay geçiş döneminde ticari işletmelerin kullandığ 1 hangi tanıtım - reklam stratejilerini kullanmaktadır?

3. Vakıf üniversitelerinin yatay geçişe ilişkin yürüttüğü kampanyalar vizyon ve misyonları ile ne kadar örtüşmektedir?

Araştırmanın hipotezine göre, vakıf üniversiteleri yatay geçiş döneminde yürüttükleri reklam kampanyaları ile ticari işletmeler ile benzer stratejiler uygulayarak, misyon ve vizyonlarından uzak bir mesaj vermektedir. Üniversitelerin misyon ve vizyon tanımlarında yer verdikleri "toplumsallık", "bilime katkı", "bilgi üretme" gibi evrensel ilkelerin ön plana çıkartarak reklam tanıtım stratejisi izlemesi, üniversitelere yönelik "ticarileşme", "şirketleşme" algısına dair önemli değişim/dönüşümler içerecektir.

Araştırmanın evrenini Türkiye'de 2018-2019 Akademik Yılı kapsamında faaliyet yürüten 72 vakıf üniversitesi oluşturmaktadır. Evrenin genişliği nedeniyle nitel araştırma geleneği içerisinde yer alan amaçlı örnekleme yöntemlerinden biri olan ölçüt örnekleme kullanılmıştır. Amaç nicel veri genişliği elde ederek genellemeler yapmak değil, veri derinliğine ulaşarak, araştırma sorularına kapsamlı yanıt bulmaktır. Dolayısıyla çalışmanın örneklemi en çok öğrenciye sahip olan 10 vakıf üniversitesi ile sınırlandırılmıştır. Patton'un ölçüt örnekleme yöntemine göre; araştırmacının kendisi bir ölçüt oluşturabilir veya mevcut olan bir ölçüt listesinden faydalanabilir. (Yıldırım ve Şimşek, 2018).

Araştırma kapsamında öncelikle vakıf üniversitelerinin web siteleri ve sosyal medya hesapları taranmış, yatay geçiş ile ilgili paylaşımları incelenmiş ve elde edilen veriler araştırma sorularına yanıt vermek üzere betimsel analiz yöntemi ile irdelenmiştir. Nitel araştırma yöntemleri içerisinde yer alan betimsel analiz, elde edilen verilerin çalışma kapsamında belirlenen temalar kapsamında resmedilmesi, tanımlanması ve yorumlanmasını içermektedir. Araştırmada elde edilen bulgular, araştırmanın hipotezlerinı s1namak amacıyla özetlenmiş ve yorumlanmış şekilde sunulmaktadır. 


\section{Araştırmanın Bulguları}

\section{Yatay Geçiş Oranlarn}

Yatay geçiş dönemi, vakıf üniversitelerinin öğrenci kazanmaları için önemli bir süreçtir. Tercih dönemlerinde farklı üniversiteleri seçerek yerleşen öğrenciler, yatay geçiş ile başka bir üniversitede eğitimlerine devam etme haklarına sahip olmaktadır. Böylece üniversiteler tercih dönemi dışındaki dönemlerde de yeni öğrenci alma fırsatı bulmaktadır. YÖK tarafından hazırlanan Yükseköğretim Kurulu Raporu 2019'a göre 2018/2019 eğitim öğretim yılında yatay geçişle vakıf üniversitelerine gelen toplam öğrenci sayısı 3.977, öğrencisi olduğu vakıf üniversitelerinden yatay geçişle ayrılan öğrenci sayıS1 13.212'dir. Yatay geçişle vakıf üniversitelerine gelen ve ayrılan öğrenci sayılarına ilişkin veriler, vakıf üniversitelerinden devlet üniversitelerine yatay geçişle geçen öğrenci sayısının yüksek olduğunu göstermektedir. Raporda, oransal olarak en fazla yatay geçişle öğrenci alan vakıf üniversitelerine ilişkin verilere göre, 4 bin 45 öğrencisi bulunan İstanbul Şişli Meslek Yüksekokulu 651, 2 bin 92 öğrencisi bulunan Avrupa Meslek Yüksekokulu 293, 6 bin 184 öğrencisi bulunan İstanbul Esenyurt Üniversitesi 470, 7 bin 513 öğrencisi bulunan Biruni Üniversitesi 491, 14 bin 130 öğrencisi bulunan İstanbul Kültür Üniversitesi 903 öğrenciyi yatay geçişle almıştır. Yine rapora göre, 2 bin 897 öğrencisi bulunan Antalya Bilim Üniversitesi'nden 453, 6 bin 184 öğrencisi bulunan İstanbul Esenyurt Üniversitesi'nden 904, 5 bin 248 öğrencisi bulunan İstanbul Şehir Üniversitesi'nden 662, bin 314 öğrencisi bulunan İstanbul 29 Mayıs Üniversitesi 142 ve 3 bin 860 öğrencisi bulunan İstanbul Gedik Üniversitesi'nden 285 öğrenci yatay geçişle başka üniversitelere geçiş yapmıştır. Vakıf Yükseköğretim Kurumları Raporu'nda yer alan veriler, bu çalışmada önemli bir soru olan, "Vakıf üniversiteleri için yatay geçiş nedir?" sorusuna yanıt verecek niteliktedir. Yatay geçişle üniversite veya yüksekokul değiştiren öğrenci sayısının mevcut öğrenciye oranı yüzde 16,1'e kadar çıkmaktadır. Vakıf üniversiteleri - temel gelir kaynağı öğrenci eğitim/öğretim ücreti- için bu oranlarla önemli bir girdi sağlanmaktadır. Dolayısıyla vakıf üniversiteleri için yatay geçiş dönemi ekonomik açıdan önemli bir süreçtir. 


\section{Yatay Geçiş Kampanyaları}

Vakıf üniversiteleri yatay geçiş sürecinde Tercih Tanıtım Dönemlerinde olduğu gibi reklam/tanıtım kampanyalarına yönelmektedir. Üniversitelerin web sayfalarında, "Online Başvuru Formları", "Canlı Whatsapp Destek Hatları", "Yatay Geçiş Tercih Robotu", "Sıkça Sorulan Sorular", "Yatay Geçiş Burs Başvurusu" ve "Yatay Geçiş Yapan Öğrencilerden Videolar", "Yatay Geçiş ve Tercih Danışmanları" gibi başlıklar altında doğrudan yatay geçiş başvurusu yapacak öğrencilere hitap eden uygulamalar yer almaktadir.

Üniversitelerin web sayfaları dışında sosyal medya platformlarında ve dijital arama motorlarında yatay geçiş reklamlarına yer verdikleri görülmektedir. Üsküdar Üniversitesi'nin 'Yatay Geçişte 'Üsküdar' Fark1 \%75'e Varan Burs İmkanı", Altınbaş Üniversitesi'nin "Yatay Geçiş ile Altınbaş'lı olma şansın devam ediyor.", Nişantaşı Üniversitesi'nin “\%75 Burs Desteği ile Yatay Geçiş Yap, Yatay Geçiş fırsatı ile 2 dönem ücretine +1 dönem bizden sana destek!" sloganları ile Google'de yayınladığı reklamlar, yatay geçişi düşünen veya planlayan öğrencilerin arama motorona girdiğinde doğrudan karşısına çıkmaktadır.

Dijital platformların yanı sıra, geleneksel medyada haberler yoluyla da yatay geçiş tanıtımları yapıldığı görülmektedir. Tüketicinin dikkatini çekmek ve reklamın inandırıcılığın arttırmak amacıyla yapılan ve haber niteliği taşıyan advertorialler yatay geçiş sürecinde öğrenci adaylarına seslenildiği ve bilgi verildiği görülmektedir. Advertorialler, editoryal veya tanıtım materyali olarak göründüğü için standart biçimdeki reklamlardan daha fazla ilgi çekmektedir (Özel ve Öksüz, 2015). İstinye Üniversitesi Genel Sekreteri Burak Kılanç ile yapılan "Yatay Geçiş öğrenciler için büyük bir fırsat başlıklı haber" (Hürriyet Gazetesi, 2020) Nişantaşı Üniversitesi Genel Sekreteri Dr. Öğr. Üyesi Mehmet Altuntaş ile yapılan "Yatay Geçişte hedef geleceğin meslekleri" başlıklı haber (Hürriyet Gazetesi, 2019), Nişantaşı Üniversitesi Rektör Danışmanı Sibel Baykut ile yapılan "Okuduğu bölümden memnun olmayana pratik yöntem yatay geçiş" başlıklı haber (Yeni Akit Gazetesi, 2020) çeşitli medya kuruluşlarında yayınlanan tanıtım içeren haberlere örnek gösterilebilir.

Üniversitelerin gerçekleştirdiği reklam tanıtım faaliyetlerinin yanı sıra Yatay Geçiş Tercih Danışmanlığı hizmeti veren kişi veya firmalar da ortaya 
çıkmaya başlamıştır. Doğrudan öğrencilerle iletişim kuran danışmanlar, yatay geçiş işlemlerinin takibi ve sonuçlandırılmasında aktif rol almaktadır. Yatay geçiş için özellikle sosyal medyanın kullanıldığı, "Öğrenci İtiraf” adı altında açılan platformlarda yatay geçiş reklamlarının sıklıkla yer aldığı ve öğrencilerle iletişime geçildiği görülmektedir. "İtiraf" sayfalarında yer alan paylaşımlarda özellikle, tanıtımı yapılan üniversitenin burs olanakları, ekstra fiyat indirimi, ders muafiyeti, bütünleme sinav hakkı, staj olanakları, ücretsiz yaz okulu, devamsızlık ve geçme notu konulu içerikler yer almaktadir.

\section{Reklam ve Tanttım Analizi}

Yatay geçiş döneminde vakıf üniversitelerinin yayınladıkları reklamlarda verilen mesaj bu araştırmanın başka bir sorusudur. Genellikle rekabet üzerinden şekillenen ticari reklamlar, bir hizmeti veya bir ürünü kitlelere tanitma ve kitleleri bu ürünü almaya, kullanmaya teşvik etmek için geleneksel veya dijital medya ortamları kullanılarak yapılan tanıtımlardır. Bu çalışma kapsamında, 2018 / 2019 Akademik yılında en çok öğrencisi bulunan 10 vakıf üniversitesinin web sayfaları ve sosyal medya hesaplarından bir örneklem oluşturulmuştur. Örneklem kapsamında yer alan üniversitelerin web sayfaları ve sosyal medya hesapları incelenmiş, 4 üniversitede yatay geçiş içerikli reklam tanıtım içerikleri bulunmadığı için, 6 üniversitenin reklam tanitım içerikleri analiz birimini oluşturmuştur. Reklam ve Tanıtım Konusu; "Kurumsal İmaj, Genel ya da Bölüm Tanıtım, Akademik Kadro ya da Öğrenci, Kampüse Davet, Teknik Altyapı, Donanım ve/veya Nitelikli Eğitim, Akademik, Bilimsel, Sanatsal, Sportif Başarı ya da Yenilik, Çevre, Toplum, Demokrasi, Sanat, Spor ya da Bilime Katkı, Uluslararası İlişkiler ve Yurtdışı Olanakları, Meslek, İstihdam ve Kariyer Olanakları, Burs Olanakları ve Ücret ile Sosyal Olanaklar" başlıkları altında kategorilendirilmiştir. Reklam ve Tanıtım Stratejileri ise; Kotler'in sınıflandırmasına dayanarak Sahicilik, Satış Özendirme, Topluluk Oluşturma, Online'dan Offline'a Çağırma ve İnsani Özellikler Gösterme başlıkları altında değerlendirilmiştir (Kotler, 2017). 
Tablo 1. Örneklemde Yer Alan Vakı Üniversitelerinin Slogan, Tema ve Reklam Strateji-

\begin{tabular}{|c|c|c|c|}
\hline ÜNIVERSITE & Yatay Geçiş Slogan1 & Tema & Reklam Stratejisi \\
\hline $\begin{array}{l}\text { Beykent } \\
\text { Üniversitesi }\end{array}$ & $\begin{array}{l}\text { İşte Gelecek Hayallerine Doğru Yatay Geçiş } \\
\text { Başladı! \% } 25 \% 50 \text { İndirim Olanakları }\end{array}$ & $\begin{array}{l}\text { Burs Olanakları } \\
\text { ve Ücret }\end{array}$ & Satış Özendirme \\
\hline $\begin{array}{l}\text { İstanbul Medipol } \\
\text { Üniversitesi }\end{array}$ & $\begin{array}{l}\text { Bahar Dönemi Yatay Geçiş Başvuruları/ Medipol'de } \\
\text { yatay geçis firsatıyla geleceğine dokun. Başvurular için } \\
\text { web sitemizi ziyaret ediniz. }\end{array}$ & $\begin{array}{l}\text { Kariyer } \\
\text { Olanakları }\end{array}$ & Satış Özendirme \\
\hline $\begin{array}{l}\text { İstanbul Bilgi } \\
\text { Üniversitesi }\end{array}$ & $\begin{array}{l}\text { Yatay Geçişle Bilgi'ye / Bilgi'li Ol! Bilgi'de yatay geçiş } \\
\text { başvurularıyla ilgili detaylı bilgi almak için tıkla. }\end{array}$ & Kurumsal İmaj & $\begin{array}{l}\text { Satış Özendirme } \\
\text { Topluluk Oluş- } \\
\text { turma }\end{array}$ \\
\hline $\begin{array}{l}\text { İstanbul Okan } \\
\text { Üniversitesi }\end{array}$ & $\begin{array}{l}\text { İş Yaşamına En Yakn Üniversite / Yatay Geçiş Başarı- } \\
\text { nı \% } 50 \text { ile destekliyoruz. }\end{array}$ & $\begin{array}{l}\text { Burs Olanakları } \\
\text { ve Ücret }\end{array}$ & Satış Özendirme \\
\hline $\begin{array}{l}\text { Nişantaşı } \\
\text { Üniversitesi }\end{array}$ & $\begin{array}{l}\text { Okuduğun Bölümden Memnun Değilsen, Yatay Geçiş } \\
\text { lle Haydi Gel / Yatay Geçişle Nişantaşı Üniversitesi } \\
\text { Meslek Yüksekokulu'na geçiş yap 2+1 dönem firsatını } \\
\text { kaçırma. }\end{array}$ & $\begin{array}{l}\text { Kurumsal İmaj } \\
\text { Burs olanakları } \\
\text { ve Ücret } \\
\text { Kampüse Davet }\end{array}$ & $\begin{array}{l}\text { Satı̧ Özendirme } \\
\text { Online'dan } \\
\text { Offline'a çağırma }\end{array}$ \\
\hline $\begin{array}{l}\text { Üsküdar } \\
\text { Üniversitesi }\end{array}$ & $\begin{array}{l}\text { Yatay Geçişte "Üsküdar" Farkı / \% 75'e varan burs } \\
\text { imkanı }\end{array}$ & $\begin{array}{l}\text { Burs Olanakları ve } \\
\text { Ücret }\end{array}$ & Satı̧ Özendirme \\
\hline
\end{tabular}

Çalışma kapsamında analiz birimi içerisinde yer alan 6 vakıf üniversitesinin, yatay geçiş sürecini kapsayan 13 Ocak 2020 ile 14 Şubat 2020 tarihleri arasında yapmış olduğu 'yatay geçiş konulu' paylaşımlarda yer alan slogan, tema ve reklam stratejisi Tablo 1'te görülmektedir. Araştırmanın yanıt aradığı temel sorulardan biri "Vakıf üniversitelerinin yatay geçiş kampanyalarında kullandıkları sloganların ve öne çıkardıkları temalar nelerdir?" sorusudur. Beykent Üniversitesi ve İstanbul Medipol Üniversitesi'nin sloganlarında satı̧̧ özendirme stratejisini kullandığı tespit edilmiş̧ir. Bireysel başarı ve kariyer fırsatlarının öne çıkarıldığı sloganlarda, "Hayallerini gerçekleştirme" ve "gelecek" vurgusu yapılmıştır. Ekonomik krizler, siyasal gerilimler, işsizlik, yoksulluk, güvencesizlik gibi sorunlar karşısında, vakıf üniversiteleri tarafından öğrenci adaylarına ve dolayısıyla gençlere verilen mesaj; bireysel kurtuluştur.

Satış özendirme stratejisi kapsamında değerlendirilen bir başka tema ise -Beykent, Okan, Nişantaşı, Üsküdar Üniversitesi'nin sloganlarına görüleceği üzere- burs olanakları ve ücrettir. 'Yatay Geçiş Başarını \% 50 ile destekliyoruz', '\% 75'e varan burs imkanı' ve hatta ' $2+1$ dönem fırsatını kaçırma' ve yanı sıra 'İş yaşamına en yakın üniversite' sloganları eğitimin metalaşması bağlamında oldukça önemlidir. Özsoy’a göre, neo-liberal politikaların eğitim alanında etkilerinin artmasıyla metalaştırılan ve sanayi işbirliğine yönelen eğitim tarzı ile eğitim gerçek doğasından uzaklaşmış; öğrenciler para karşılığı hizmet alan kişilere dönüşmüştür. Öğrencinin gerçek hedefi ise iyi 
bir eğitim almaktan, yaygın geçerliliği olan ve kabul gören bir sertifika ya da diploma sahibi olmaya evrilmiş, bu bağlamda eğitim iyi bir konuma gelebilmenin aracı haline gelmiştir. (Dağtaş ve Ünal, 2019)

Bilgi Üniversitesi reklamında ise kurumsal imajına / marka değerine vurgu yapılmış ve aday öğrenciye hem satış özendirme hem de topluluk oluşturma stratejisi kapsamında çağrı yapılmıştır. Özellikle "Bilgi'li Ol" sloganı, ticari işletmelerin kendi hedef kitlelerinden bir topluluk yaratma ve hatta onlara bir isim vererek ait olduklarını hissettikleri bir alan yaratmayı amaçlaması bağlamında dikkat çekicidir. Kotler'in altını çizdiği üzere gelecekte online ve offline iletişim bir arada yürütülmekte ve birbirlerine daha fazla yaklaşmaktadır. İşletmeler, gelenekseli dışlamadan, yeni bir dijatal iletişim anlayışını benimsemektedir. Bu anlayışa göre, müşteriler ile online ve offline etkileşimler birleşmektedir. (Kotler, 2017). Nişantaşı Üniversitesi'nin sloganında yer alan 'Kampüse davet' vurgusu 'Online'dan Offline'a Çağırma' stratejisine paralellik göstermektedir.

\section{Reklamlarnn Misyon ve Vizyonla İlişkisi}

Örneklemde yer alan üniversitelerin web sayfalarında yayınlanan misyon ve vizyon tanımlarında öne çıkan ifadeler Tablo 2'de yer almaktadır. Misyon ve vizyon tanımlarında, bilimsel üretim, bilgi paylaşımı, toplumsal katkı ve evrensel değerlerin ön plana çıtı̆̆ı görülmektedir.

Tablo 2. Vakı Üniversitelerinin Web Sayfalarnda Yer Alan Vizyon ve Misyon Tanımlarn

\begin{tabular}{|c|c|c|}
\hline & MISYYN & VIZYYON \\
\hline $\begin{array}{l}\text { Beykent } \\
\text { Üniversitesi }\end{array}$ & $\begin{array}{l}\text { Bilgi ve teknoloji üretimi, toplumsal yarar, fiziki ve teknolojik altyapı, } \\
\text { sosyal ortam, eğitim-uygulama programları ve öğrenme kaynaklarına } \\
\text { erişim, kişisel ve mesleki gelişim, toplumu tanıma, } \\
\text { etik değerlere bağlılık ve çevreye duyarlılık }\end{array}$ & Küresel ölçek \\
\hline $\begin{array}{l}\text { İstanbul } \\
\text { Medipol } \\
\text { Üniversitesi }\end{array}$ & $\begin{array}{l}\text { Kalıcı üstünlük, bilim ve teknoloji üretimi, topluma } \\
\text { ve } \\
\text { evrensel bilime katkı }\end{array}$ & $\begin{array}{l}\text { Girişimcilik, gelişime } \\
\text { açılık, dinamizm, } \\
\text { bilim ve topluma yön } \\
\text { verme, öncü }\end{array}$ \\
\hline $\begin{array}{l}\text { İstanbul Bilgi } \\
\text { Üniversitesi }\end{array}$ & $\begin{array}{l}\text { Bilime, sanatsal üretime ve teknolojik gelişmelere katkı; özgür düşünce, } \\
\text { toplumsal sorumluluk, bireysel, mesleki ve akademik gelişim, uluslararası } \\
\text { yetkinlik, etik ve mesleki nesnellik, çok boyutlu kalite, topluma hizmet }\end{array}$ & $\begin{array}{l}\text { Bilim ve sanatta } \\
\text { özgürlükçü, uluslararası }\end{array}$ \\
\hline $\begin{array}{l}\text { İstanbul Okan } \\
\text { Üniversitesi }\end{array}$ & $\begin{array}{l}\text { Cumhuriyetin temel değerlerini özümsemiş, ulusal ve evrensel sorunlara } \\
\text { duyarlı, analitik düşünce yeteneğine sahip, eleştirel düşünebilen, girişimci, } \\
\text { yenilikçi..., toplumsal fayda, etik değer, evrensel kültür, dünya vatandaşı, } \\
\text { özgün araştırmalarla bilime katkı, sosyal sorumluluk ve çevre bilinci, } \\
\text { toplum gereksinimler }\end{array}$ & $\begin{array}{l}\text { Toplumun ve iş yaşa- } \\
\text { minın gereksinimlerine } \\
\text { evrensel standartlarda } \\
\text { yanit verebilen, yenilik- } \\
\text { çi, öncü dünya üniversi- } \\
\text { tesi }\end{array}$ \\
\hline Nişantaşı & Bilgi üretme, analitik ve eleştirel düşünme, dijitalleşen, otomasyon & Dijital teknoloji, yapay \\
\hline
\end{tabular}




\begin{tabular}{|c|c|c|}
\hline Üniversitesi & sistemleri ve robotik teknolojiler, geleceğin meslekleri, yaşam boyu öğrenme & \begin{tabular}{l}
\multicolumn{3}{l}{ zekâ, geleceğin meslek- } \\
lerinde önemli roller \\
üstlenecek nesil yetiş- \\
tirme
\end{tabular} \\
\hline $\begin{array}{l}\text { Üsküdar } \\
\text { Üniversitesi }\end{array}$ & $\begin{array}{l}\text { Ülkenin sosyo-ekonomik ve kültürel yapısına katkı sağlama, uluslararası } \\
\text { düzeyde eğitim ve araştırma imkânı, kentsel ve bölgesel kalkınmaya katkı } \\
\text { sağlama, öncü ve örneküniversite }\end{array}$ & $\begin{array}{l}\text { Bilim, hizmet üretme ve } \\
\text { nitelikli insan yetiştiril- } \\
\text { me, ülkemizin kişisel ve } \\
\text { toplumsal ruh sağlığını } \\
\text { korumak ve geliştirmek }\end{array}$ \\
\hline
\end{tabular}

Vakıf üniversitelerinin yatay geçiş reklamlarında sunduğu iletilerin, vizyon ve misyonları ile ne kadar örtüştüğü bu araştırmanın başka bir sorusudur. Yatay geçiş reklamlarında; üniversitelerin misyon ve vizyonlarında öne çıkan; toplumsal fayda, bilgi üretimi, bilimsel gelişim, sosyal sorumluluk gibi unsurlar yerine özellikle rakamsal ifadelerle gösterilen indirim/burs olanaklarının mesaj olarak iletildiği görülmektedir. Ürünün tüketiciye cazip gelmesi ve satın alınabilirliğin arttırılabilmesi için fiyat indirimleri ticari reklamlarda sıklıkla öne çıkartılmaktadır. Satış odaklı reklamcılık olarak da nitelendirilen bu reklamlar ile müşterinin ürünü satın alması için bir cazibe sunulmaktadır. Vakıf üniversiteleri de benzer şekilde, yatay geçişte öğrencileri fiyat indirimleri ile cezbetmeye çalışmaktadır. Ancak yatay geçişte cazibenin sadece fiyat üzerinden yapılması ve rakamların öne çıkarılması, eğitimin ticari bir metaya dönüşmesi ve üniversitenin de ticari bir işletme olarak konumlandırılmasıdır.

\section{Tartışma ve Sonuç}

Toplumsal gelişim ve aydınlanmada önemli bir gücü barındıran üniversiteler, günümüz ekonomik-politik yapısı içerisinde birer ticari işletme olarak konumlanmaya başlamıştır. Ticarileşme sürecinde, bilgi üretiminin toplumsal alana sağladığı katkı yerine, ülke ekonomisine, serbest piyasaya veya sanayiye sunduğu katkı ön plana çıkmaktadır. Üniversitelerin işletmeye öğrencilerin müşteriye dönüştüğü bu süreçte, vakıf üniversitelerinin reklam ve tanıtım kampanyalarında kullandığı mesajlar dikkat çekmektedir.

$\mathrm{Bu}$ çalışma yatay geçiş dönemlerinde vakıf üniversitelerinin reklam kampanyalarına odaklanmış, reklamlarda kullanılan mesajlar analiz edilerek, ticari reklamlarla karşılaştırılmıştır. Çalışma kapsamında vakıf üniversitelerinin topluluk oluşturma ve satış özendirme gibi ticari reklam stratejilerini kullandığı, “\% 25 \%50 İndirim Olanakları”, “\%75'e varan Burs İmkanı”, "2+1 Dönem fırsatını kaçırma” gibi sloganlarla yükseköğretimi ticari bir 
meta olarak sunduğu görülmüştür. Kar amacı gütmeyen eğitim ve öğretim kurumları olarak mevzuatta tanımlanan vakıf üniversitelerinin, "Okuduğun Bölümden Memnun Değilsen, Yatay Geçiş İle Haydi Gel“ örneğinde olduğu gibi rekabetçi reklam söylemini kullanarak, birer ticari işletme gibi konumlandığı, satış odaklı ticari reklamlarla eğitimi metalaştırdığ tespit edilmiştir.

Çalışmada ayrıca, vakıf üniversitelerinin misyon ve vizyonlarında belirttikleri; toplumsal fayda, bilimsel gelişim ve üretim, evrensellik, eleştirel bakış açısı gibi değerler yerine, kişisel başarı, gelecek ve kariyer odaklı eğitim/öğretim mesajları üzerinden reklam stratejileri oluşturtuğu ortaya konulmuştur. Vakıf üniversitelerinin bu tür stratejilere ağırlık vermesi, üniversitelerin şirketleşmesi ve öğrencilerin müşterileşmesi algısını oluşturabilecek etkiye sahiptir. Dolayısıyla vakıf üniversitelerinin, günümüz ekonomi koşullarını da göz ardı etmeden, misyonlarında bellirttikleri; bilimsellik, evrensellik ve toplumsal yarar işlevlerine uygun ifade ve söylemleri tanitım reklam stratejilerine dahil etmesi en azından bireysel ve toplumsal algi için katkı sağlayacaktır. 


\title{
EXTENDED ABSTRACT
}

\section{Analysis Of Advertisements Campaigns That The Foundation Universities Published Under The Undergraduate Transfer}

\author{
Evin Doğan - Elif Miral Oktay \\ İstanbul Şişli Vocational School Of Higher Education
}

Undergraduate transfer refers to the pursuance of education of a higher education student in another program or department with a similar grade of the former. Applied in two methods, internal or external, students have rights to transfer to another department internally or another university within the context of the undergraduate transfers. Following the latest regulations made by the Council of Higher Education (YÖK), undergraduate transfers gained a gripping attention of private universities. Private universities started major commercial campaigns for the undergraduate transfers which gives a massive boost to the increase of student quantity. Private universities are significant for this research because the number of this kind of universities increases and in parallel with this various problems come up.

Turkey's first private universities which gained the status of private universities officially via Law 3785 effectuated in 1992 are Bilkent, Kadir Has and Koç University. Following the year of 1992 the number of the private universities started to increase. By year of 2020, 72 private universities are in the service, beside these there are 5 vocational schools. In accordance with Code of Private Universities these universities are not commercial entities, they are universities with public entity which deliver high profile education, scientific research, publication and consulting. The qualification of private universities is defined in article 130 of Turkish constitution as of, "Institutions, of higher education under the supervision and control of the State, can be established by foundations in accordance with the procedures and principles set forth in the law provided that they do not pursue lucrative aims." When relavant regulations considered, private universities are expected to not being evaluated as a commercial entity that established for getting commercial income (Budak, 2010). Private universities, which are defined as 
public entities and educational institutions with no profit motivations, started to comply with market mechanisms regarding of increasing the number of state and private universities and competition environment. Private universities have tended to use various marketing and selling strategies like commercial entities in free market.

The aim ise to full quota of student by reaching candidate students and at the same time establish positive image regarding institutional base. Private universities, especially in preference periods, focus to meet the target group and try to influence the target group's tendencies via advertisements and introductory films. This study focuses to advertising/marketing campaigns of private universities that try to reach candidate students via websites and social media posts in the period of application for undergraduate transfers. This study is to evaluate the social functions of universities that are defined with the mission of producing scientifically knowledge and acting as educational and research institutions for public interest, with analyzing of advertisement of these universities

Within the scope of this study, below questions are tried to be answered

1- What are the themes and catch lines used and highlighted by private universities in the campaign of undergraduate transfers?

2- Which advertising/marketing strategies particular to commercial companies are used by private universities in the period of undergraduate transfer?

3- How much do campaigns of private universities used for undergraduate transfer overlap with their vision-mission?

In accordance with the hypothesis of the study private universities gave irrelevant messages regarding their vision-mission by similar strategies with commercial companies via advertisement campaigns that are used in the period of undergraduate transfers. Delivering advertising/marketing strategy in their vision-mission which highlights universal principles like 'collectivism' 'contribution to science' and 'producing knowledge' would contain significant transformations of commercial perception for universities. Within the scope of the study, the websites and social media posts, especially on undergraduate transfers of ten private universities which have most students have been searched and data have been examined with the method of descriptive analysis to get answer for the problematiques of the study. Descriptive analysis contains description and evaluating data which obtained 
within the scope of the study. Findings obtained during the study with the aim to test the hypothesis of the study are represented as evaluated and summarized.

In accordance with the findings obtained during the study it is seen that private universities use commercial advertising strategies like selling incentive and group establishing and represent higher education as a commercial merchandise by using slogans like "\%25-50 sale" "Scholarship opportunities up to $\% 75^{\prime \prime}$ and "Don't miss the opportunity for $2+1$ semesters." It is determined that private universities, which are defined as public entities and educational institutions with no profit motivations, position themselves as a commercial entity, merchandise the education via selling-based commercial advertisements as seen like in sample of "If you are not pleased from department that you study, come with undergraduate transfer."

This study is focused on the advertisement campaigns of undergraduate transfer processes of private universities, which are, in contrast, defined with the mission of generating information, disseminating and providing social benefit. The aim is to analyze the advertisements launched by universities during the transfer period, and evaluate them in the context of universities' social missions, which are defined as science and education institutions focused on education and research, producing scientific knowledge and disseminating it for public benefit. Considering the data collected during this research, universities, ignoring the primary functions and values of their vision \& mission definitions, promote discount and scholarship opportunities and stimulate commercial marketing strategies. Universities should pursue marketing strategies with universal values defined in their vision \& mission discourse such as "collectivism", "scientific contribution" and "production of knowledge", which in return might help universities transform/reverse the perception of commercialization.

\section{Kaynakça / References}

Baskan, G. A. (2001). Türkiye'de Yükseköğretimin gelişimi. Ankara: Ankara Gazi Eğitim Fakültesi Dergisi.

Bektaş, S., Fidan, Ş., ve Keçeci, S. B. (2011). Yükseköğretimde sorunlar ve öneriler. TMMOB Türkiye 13. Harita Bilimsel ve Teknik Kurultayı. Ankara.

Bingöl. (2012). Üniversite özerkliğinin değişen tanımı ve üniversitelerin yeniden yapılandırnlmass. Ankara: Hacettepe Hukuk Fakültesi Dergisi. 
Bingöl, B. (2012). Üniversite özerklĭginin değişen tanımı ve üniversitelerin yeniden yapılandırlması. Ankara: Hacettepe Hukuk Fakültesi Dergisi.

Budak, Y. (2010). Katma değer vergisi kanunu: Kültür ve eğitim istisnass: Vakıf Üniversiteleri. Ankara Üniversitesi Hukuk Fakültesi Dergisi, 449-465.

Cumhurbaşkanlığı Mevzuat Bilgi Sistemi. (2020, Şubat 1). Cumhurbaşkanlığı Mevzuat Bilgi Sistemi. www.mevzuat.gov.tr: https://www.mevzuat.gov.tr/mevzuat?MevzuatNo=9768\&MevzuatTur=7\& MevzuatTertip $=5$ adresinden alınmıştır

Cumhurbaşkanlığı Mevzuat Bilgi Sistemi. (2020, Şubat 1). Cumhurbaşkanlı̆̆ı Mevzuat Bilgi Sistemi. www.mevzuat.gov.tr: https://www.mevzuat.gov.tr/mevzuat?MevzuatNo=2709\&MevzuatTur=1\& MevzuatTertip $=5$ adresinden alınmışır

Dağtaş, E., ve Ünal, M. A. (2019). Eğitim haberlerinin metalaşmasını reklam ve reklam haberler üzerinden okumak. Maltepe Üniversitesi Illetişim Fakültesi Dergisi, 3861.

Değirmencioğlu, S., ve İnal, K. (2015). Yükseköğretimin serbest düşüşü: Özel üniversiteler. İstanbul: Ayrintı Yayınları.

Dolgun, U. (2011). Yirmibirinci yüzyllda yükseköğretimin yeni misyonu: Ticari üniversiteler ve girişimci akademisyenler. Sosyoloji Konferanslan, 15-41.

Einstein, M. (2017). Advertising what everyone needs to know. London: Oxford University Press.

Ersun, C. (2011). Teknoparklar teknolojik bilginin ticarileşmesi. İstanbul: İstanbul Ticaret Odasi Yayınları.

Goldman, R. (1992). Reading Ads Socially. London and Newyork: Routledge.

Hürriyet Gazetesi. (2019, Aralık 25). Hürriyet Gazetesi. www.hurriyet.com.tr: www.hurriyet.com.tr adresinden alınmıştır

Hürriyet Gazetesi. (2020, Ocak 22). Hürriyet Gazetesi. www.hurriyet.com.tr: www.hurriyet.com.tr adresinden alınmıştır

Karaboğa, M. T. (2018). Küreselleşme sürecinin eğitim kurumlar üzerindeki etkilerine yönelik bir tartışma. Kurgzistan: Akademik Bakış Dergisi.

Kotler, P. (2017). Pazarlama 4.0, gelenekselden dijitale geçis. İstanbul: Optimist Yayınevi.

Özel, E. K., ve Öksüz, B. (2015). Yazılı Basında Advertorial: Gazeteciler İçin Şeytanın Ta Kendisi. Dokuz Eylül Üniversitesi Sosyal Bilimler Enstitüsü Dergisi, 67-104.

Slaughter, S. (1997). Academic capitalism; Politics, policies and the entrepreneurial university. Baltimore: Johns Hopkins Universty Press.

Yeni Akit Gazetesi. (2020, Ocak 18). Yeni Akit Gazetesi. www.yeniakit.com.tr: www.yeniakit.com.tr adresinden alınmıştır 
Yıldırım, A., ve Şimşek, H. (2018). Sosyal bilimlerde nitel araştırma yöntemleri . İstanbul: Seçkin Yayınları.

Ylldız, S. (2014). Üniversiteler ne vaat ediyor? Türkiye'deki üniversitelerin basın ilanları üzerine bir içerik analizi. Anadolu Üniversitesi Sosyal Bilimler Dergisi, 155-170.

Yükseköğretim Kurumu. (2020, Şubat 1). Vakıf yükseköğretim kurumları raporu 2019. www.yok.gov.tr:

https://www.yok.gov.tr/HaberBelgeleri/Haber\%20\%C4\%B0\%C3\%A7erisind eki\%20Belgeler/Yay\%C4\%B1nlar/2019/Vakif_Yuksekogretim_Kurumlari_20 19.pdf adresinden alınmıştır

\section{Kaynakça Bilgisi / Citation Information}

Doğan, E. ve Oktay, M. E. (2020). Vakıf üniversitelerinin yatay geçiş kampanyaları kapsamında yayınladıkları reklamların analizi. OPUS-Uluslararası Toplum Araştırmaları Dergisi, 16(Eğitim ve Toplum), 6106-6125. DOI: 10.26466/opus.732714 